\title{
Morphology Test
}

National Cancer Institute

\section{Source}

National Cancer Institute. Morphology Test. NCI Thesaurus. Code C117607.

A character or string that represents the long name of the morphology assessment. 